\title{
Critical Perspectives on Television from the Frankfurt School to Postmodernism
}

\author{
Douglas Kellner \\ (http://www.gseis.ucla.edu/faculty/kellner/)
}

Paul Lazarsfeld (1942), one of the originators of modern communications studies, distinguished between what he called a "administrative research," that deployed empirical research for the goals of corporate and state institutions, and "critical research," that he associated with the Frankfurt School. Critical research situates the media within the broader context of social life and interrogates its structure, goals, values, messages, and effects. It develops critical perspectives by which media are evaluated and appraised.

Since the 1940s, an impressive variety of critical approaches to the media and television have developed. In this study, I will first present the Frankfurt School as an inaugurator of critical approaches to television studies and will then discuss how a wide range of theorists addressed what later became known as the politics of representation in critical television studies, engaging problematics of class, gender, race, sexuality, and other central components of media representation and social life. Then, I discuss how a postmodern turn in cultural studies contested earlier critical models and provided alternative approaches to television studies. I conclude with some comments that argue for a critical approach to television and media culture and in this text sketch out a comprehensive critical model that embraces production and political economy of television; textual analysis; and investigation of the effects and uses of television by audiences. As this study will indicate, such a multidimensional approach to critical media and television studies is found initially in the Frankfurt School and was developed by many other television theorists in diverse locations and from often conflicting perspectives, ranging from British cultural studies to critical feminism.

\section{The Frankfurt School and the Culture Industries}

From the classical Frankfurt School perspective, commercial television is a form of what Horkheimer and Adorno and their colleagues called "culture industry." Moving from Nazi Germany to the United States, the Frankfurt School experienced at first hand the rise of a media culture involving film, popular music, radio, television, and other forms of mass culture. ${ }^{1}$ In the United States, where they found themselves in exile, media production was by and large a form of commercial entertainment controlled by big corporations. Thus, the Frankfurt School coined the term "culture industries" to call attention to the industrialization and commercialization of culture under capitalist relations of production. This situation was most marked in the United States that had little state support of film or television industries.

To a large extent, the Frankfurt school began a systematic and comprehensive critical approach to studies of mass communication and culture, and produced the first critical theory of the cultural industries. ${ }^{2}$ During the 1930s, the Frankfurt school developed a critical and transdisciplinary approach to cultural and communications studies, combining critique of political economy of the media, analysis of texts, and audience reception studies of the social and ideological effects of mass culture and communications. They coined the term "culture industry" 
to signify the process of the industrialization of mass-produced culture and the commercial imperatives which drove the system. The critical theorists analyzed all mass-mediated cultural artifacts within the context of industrial production, in which the commodities of the culture industries exhibited the same features as other products of mass production: commodification, standardization, and massification. The culture industries had the specific function, however, of providing ideological legitimation of the existing capitalist societies and of integrating individuals into the framework of its social formation.

Key early studies of the culture industries include Adorno's analyses of popular music (1978 [1932], 1941, 1982, and 1989), television (1991), and popular phenomena such as horoscopes (1994); Lowenthal's studies of popular literature and magazines (1961); Herzog's studies of radio soap operas (1941); and the perspectives and critiques of mass culture developed in Horkheimer and Adorno's famous study of the culture industries (1972 and Adorno 1991). In their critiques of mass culture and communication, members of the Frankfurt School were among the first to systematically analyze and criticize mass-mediated culture and television within critical social theory. They were the first social theorists to see the importance of what they called the "culture industries" in the reproduction of contemporary societies, in which so-called mass culture and communications stand in the center of leisure activity, are important agents of socialization, mediators of political reality, and should thus be seen as major institutions of contemporary societies with a variety of economic, political, cultural and social effects.

Furthermore, the critical theorists investigated the cultural industries in a political context, conceptualizing them as a form of the integration of the working class into capitalist societies. The Frankfurt school was one of the first neo-Marxian groups to examine the effects of mass culture and the rise of the consumer society on the working classes, which were to be the instrument of revolution in the classical Marxian scenario. They also analyzed the ways that the culture industries and consumer society were stabilizing contemporary capitalism and accordingly sought new strategies for political change, agencies of social transformation, and models for political emancipation that could serve as norms of social critique and goals for political struggle. This project required rethinking the Marxian project and produced many important contributions -- as well as some problematical positions.

Victims of European fascism, the Frankfurt school experienced first hand the ways that the Nazis used the instruments of mass culture to produce submission to fascist culture and society. While in exile in the United States, the members of the Frankfurt school came to believe that American media culture was also highly ideological and worked to promote the interests of U.S. capitalism. Controlled by giant corporations, the culture industries were organized according to the strictures of mass production, churning out products that generated a highly commercial system of culture, which in turn sold the values, life-styles, and institutions of capitalism.

In retrospect, one can see the Frankfurt school work as articulation of a theory of the stage of state and monopoly capitalism, which became dominant during the 1930s. This was an era of large organizations, in which the state and giant corporations managed the economy and in which individuals submitted to state and corporate control. This period is often described as 'Fordism' to designate the system of mass production and the homogenizing regime of capital that wanted to produce uniform desires, tastes, and behavior. It was thus an era of mass production and consumption characterized by uniformity and homogeneity of needs, thought, and behavior 
producing a 'mass society' and what the Frankfurt school described as 'the end of the individual.' No longer was individual thought and action the motor of social and cultural progress; instead giant organizations and institutions overpowered individuals. The era corresponds to the staid, ascetic, conformist, and conservative world of corporate capitalism that was dominant in the postwar United States with its organization men and women, its conspicuous consumption, and its mass culture.

During this period, media culture was instrumental in generating the modes of thought and behavior appropriate to a highly organized and conformist social order. Thus, the Frankfurt school theory of the culture industries articulates a major historical shift to an era in which mass consumption and culture were indispensable to producing a consumer society based on homogeneous needs and desires for mass-produced products and a society based on standardization and homogeneity. It is culturally the era of highly controlled network radio and television, insipid top-forty pop music, glossy Hollywood films, national magazines, and other mass-produced cultural artifacts.

The Frankfurt School provides television and media studies with a model that articulates the dimensions of production and political economy, text analysis, and audience/reception research. The Frankfurt School addresses all of these dimensions and at its best depicts their interrelationship. Indeed, Frankfurt School critical theory provides the Big Picture, analyzing relationship between the economy, state, society, and everyday life (Kellner 1989). Thus, a critical theory of television would articulate the relationships between the economy, the state, and television, analyzing television's production process, texts, and socio-political effects and audience uses within the context of its institutional role within specific types of social organization (see Kellner 1990). I will accordingly discuss the classical Frankfurt School model of television and some specific attempts to provide analyses of television within the Frankfurt School tradition before turning to other critical approaches.

\section{The Frankfurt School and the Rise of Television}

In Dialectic of Enlightenment, Horkheimer and Adorno anticipate the coming of television in terms of the emergence of a new form of mass culture that would combine sight and sound, image and narrative, in an institution that would embody the types of production, texts, and reception of the culture industry. Anticipating that television would be a prototypical artifact of industrialized culture, Adorno and Horkheimer wrote:

Television aims at a synthesis of radio and film, and is held up only because the interested parties have not yet reached agreement, but its consequences will be quite enormous and promise to intensify the impoverishment of aesthetic matter so drastically, that by tomorrow the thinly veiled identity of all industrial culture products can come triumphantly out into the open, derisively fulfilling the Wagnerian dream of the Gesamtkunstwerk, the fusion of all the arts in one work. The alliance of word, image, and music is all the more perfect than in Tristan because the sensuous elements which all approvingly reflect the surface of social reality are in principle embodied in the same technical process, the unity of which becomes its distinctive content... Television points the way to a development 
which might easily enough force the Warner Brothers into what would certainly be the unwelcome position of serious musicians and cultural conservatives (1972: 124, 161).

Following the model of critique of mass culture in Dialectic of Enlightenment, a Frankfurt School approach to television would analyze television within the dominant system of cultural production and reception, situating the medium within its institutional and political framework. It would combine study of text and audience with ideology critique and a contextualizing analysis of how television texts and audiences are situated within specific social relations and institutions. The approach combines Marxian critique of political economy with ideology critique, textual analysis, and psychoanalytically inspired depth-approaches to audiences and effects.

T.W. Adorno's article "How to look at television" (1991) provides a striking example of a classic Frankfurt School analysis. Adorno opens by stressing the importance of undertaking an examination of the effects of television upon viewers, making using of "depth-psychological categories." Adorno had previously collaborated with Paul Lazarsfeld on some of the first examinations of the impact of radio and popular music on audiences (see Lazarsfeld 1941). While working on The Authoritarian Personality (Adorno et al 1969 [1950]), Adorno took on a position as director of the scientific branch of the Hacker Foundation in Beverly Hills, a psychoanalytically-oriented foundation, and undertook examinations of the socio-psychological roots and impact of mass cultural phenomena, focusing on television in one study (Adorno 1991) and the astrological column of the Los Angeles Times in another (Adorno 1994).

In view of the general impression that the Frankfurt School make sharp and problematic distinctions between high and low culture, it is interesting that Adorno opens his study with a deconstruction of "the dichotomy between autonomous art and mass media." Stressing that their relation is "highly complex," Adorno claims that distinctions between popular and elite art are a product of historical conditions and should not be exaggerated. After a historical examination of older and recent popular culture, Adorno analyzes the "multilayered structure of contemporary television." In light of the notion that the Frankfurt School reduces the texts of media culture to ideology, it is interesting that Adorno calls for analysis of the "various layers of meaning" found in popular television, stressing "polymorphic meanings" and distinctions between latent and manifest content. Adorno writes:

The effect of television cannot be adequately expressed in terms of success or failure, likes or dislikes, approval or disapproval. Rather, an attempt should be made, with the aid of depth-psychological categories and previous knowledge of mass media, to crystallize a number of theoretical concepts by which the potential effect of television -- its impact upon various layers of the spectator's personality -- could be studied. It seems timely to investigate systematically sociopsychological stimuli typical of televised material both on a descriptive and psychodynamic level, to analyze their presuppositions as well as their total pattern, and to evaluate the effect they are likely to produce...(1991: 136).

Adorno's examples come from the early 1950s TV shows and tend to see these works as highly formulaic and reproducing conformity and adjustment. He criticizes stereotyping in television, "pseudo-realism," and its highly conventional forms and meaning, an approach that 
accurately captures certain aspects of 1950 s television, but which is inadequate to capture the growing complexity of contemporary television. Adorno's approach to "hidden meanings" is highly interesting, however, and his psychoanalytic and ideological readings of television texts and speculation on their effects are pioneering.

Adorno's study is one of the few concrete studies of television with the Frankfurt School tradition that addresses the sort of text produced by network television and the audience for its product. While Horkheimer, Adorno, Marcuse, Habermas, and other major Frankfurt School theorists never systematically engage television production, texts, or audiences, they frequently acknowledge the importance of television in their development of a critical theory of society, or in their comments on contemporary social phenomena. Following the Frankfurt School analysis of changes in the nature of socialization, Herbert Marcuse, for instance, noted the decline of the family as the dominant agent of socialization in Eros and Civilization (1955) and the rise of the mass media, like radio and television:

The repressive organization of the instincts seems to be collective, and the ego seems to be prematurely socialized by a whole system of extra-familial agents and agencies. As early as the pre-school level, gangs, radio, and television set the pattern for conformity and rebellion; deviations from the pattern are punished not so much in the family as outside and against the family. The experts of the mass media transmit the required values; they offer the perfect training in efficiency, toughness, personality, dream and romance. With this education, the family can no longer compete (97).

Marcuse saw television as part of an apparatus of administration and domination in a one-dimensional society. In his words, "with the control of information, with the absorption of individuals into mass communication, knowledge is administered and confined. The individual does not really know what is going on; the overpowering machine of entertainment and entertainment unites him with the others in a state of anesthesia from which all detrimental ideas tend to be excluded" (104). On this view, television is part of an apparatus of manipulation and societal domination. In One-Dimensional Man (1964), Marcuse claimed that the inanities of commercial radio and television confirm his analyses of the individual and the demise of authentic culture and oppositional thought, portraying television as part of an apparatus producing the thought and behavior needed for the social and cultural reproduction of contemporary capitalist societies.

\section{Critical Perspectives From/After the Frankfurt School}

While the classical Frankfurt School members wrote little on television itself, the critical theory approach strongly influenced critical approaches to mass communication and television within academia and the views of the media of the New Left and others in the aftermath of the 1960s. The anthology Mass Culture (Rosenberg and White, editors 1957) contained Adorno's article on television and many studies influenced by the Frankfurt School approach. Within

critical communication research, there were many criticisms of network television as a capitalist institution and critics of television and the media such as Herbert Schiller, George Gerbner, Dallas 
Smythe, and others were influenced by the Frankfurt School approach to mass culture, as was C. Wright Mills in an earlier era (see Kellner 1989: 134ff).

From the perspectives of the New Left, Todd Gitlin wrote "Thirteen Theses on Television" that contained a critique of television as manipulation with resonances to the Frankfurt School in 1972 and continued to do research and writing that developed in his own way a Frankfurt School approach to television, focusing on TV in the United States (1980, 1983, 2002). A 1987 collection Watching Television contained studies by Gitlin and others that exhibited a neo-Frankfurt School approach to television, and many contemporary theorists writing on television have been shaped by their engagement with the Frankfurt School.

Of course, media culture was never as massified and homogeneous as in the Frankfurt school model and one could argue that their perspectives were flawed even during its time of origin and influence. One could also argue that other approaches were preferable (such as those of Walter Benjamin (1969), Siegfried Kracauer (1995), Ernst Bloch (1986) and others of the Weimar generation). The original Frankfurt school model of the culture industry did articulate the important social roles of media culture during a specific regime of capital. The group provided a model, still of use, of a highly commercial system of television that serves the needs of dominant corporate interests, plays a major role in ideological reproduction, and in enculturating individuals into the dominant system of needs, thought, and behavior.

Today, it is more fashionable to include moments of Frankfurt School critique of television in one's theory than to simply take a systematic Frankfurt School approach. It would be a mistake, however, to reject the Frankfurt School tout court as reductive, economistic, and representative solely of a one-dimensional "manipulation theory," although these aspects appear in some of their writings. Indeed, the systematic thrust of the Frankfurt School approach that studies television and other institutions of media culture in terms of their political economy, text, and audience reception of cultural artifacts continues to be of use. Overcoming the divide between a text-based approach to culture and an empiricist social science-based communication theory, the Frankfurt School sees media culture as a complex multi-dimensional phenomenon that must be taken seriously and that requires multiple disciplines to capture its importance and complexity. Within the culture industries, television continues to be of central importance and so critical theorists today should seek new approaches to television while building upon the Frankfurt School tradition.

Other critical studies in the past decades have researched the impact of global media on national cultures, attacking the cultural imperialism of Western media conglomerates or creeping Americanization of global media and consumer culture (Schiller, 1971; Tunstall, 1977). Schiller and others focused on the political economy of television and its role nationally and globally in promoting corporate interests. In Mass Communications and American Empire (1971), Herbert Schiller traced the rise of the commercial broadcasting industry in the United States, its interconnection with corporate capitalism and the military, and the use of communications and electronics in counterrevolution, such as Vietnam, and in promoting a global capitalist economic Empire.

Political economy approaches to television charted the consequences of dominance of TV production by corporate and commercial interests and the ways that programming was geared toward concerns of advertisers and securing the largest possible mass audience. Herman and 
Chomsky (1988) presented "filters" by which corporate, advertising, media gatekeeping, and conservative control excluded certain kinds of programming while excluding less mainstream and conservative material. Scholars studying media imperialism traced how the importation of U.S. programming and broadcasting institutions and structures impacted broadcasting on a global scale.

Some critical approaches focused on the social effects of television, often decrying excessive TV violence. On television and violence, some literature continued to assume that violent representations in the media directly cause social problems. A more sophisticated social ecology approach to violence and the media, however, was developed by George Gerber and his colleagues in the Annenberg School of Communication. Gerbner's group has studied the "cultural environment" of television violence, tracking increases in representations of violence and delineating "message systems" that depict who exercises violence, who is the victim, and what messages are associated with media violence. A "cultivation analysis" studies effects of violence and concludes that heavy consumers of media violence exhibit a "mean world syndrome" with effects that range from depression to fearful individuals voting for rightwing law and order politicians, to the exhibition of violent behavior (Gerbner 2003). ${ }^{4}$

Another approach to violence and the media is found in the work of Eysenck and Nias (1978) who argue that recurrent representations of violence in the media desensitize audiences to violent behavior and actions. The expansion of youth violence throughout the world and media exploitation of sensational instances of teen killings in the U.S., Britain, France, Germany and elsewhere intensified focus on media and violence and the ways that rap music, video and computer games, television and film, and other types of youth culture have promoted violence. ${ }^{5}$

In addition to seeing television as a social problem because of growing societal violence, from the 1960s to the present, left-liberal and conservative media critics coalesced in arguing that mainstream media promote excessive consumerism and commodification. FFC commissioner Newton Minow described TV in the 1960s as a "Vast Wasteland" and the term was used by both conservative and left-liberal critics to assail what was perceived as the growing mediocrity and low cultural level of television. This view is argued in sociological terms in the work of Daniel Bell who asserts in The Cultural Contradictions of Capitalism (1978) that a sensate-hedonistic culture exhibited in popular media and promoted by capitalist corporations was undermining core traditional values and producing an increasing amoral society. Bell called for a return to tradition and religion to counter this social trend that saw media culture as undermining morality, the work ethic, and traditional values.

In Amusing Ourselves to Death (1986), Neil Postman argued that popular media culture and especially television has become a major force of socialization and was subverting traditional literacy skills, thus undermining education. Postman criticized the negative social effects of the media and called for educators and citizens to intensify critique of the media. Extolling the virtues of book culture and literacy, Postman called for educational reform to counter the nefarious effects of media and consumer culture.

Indeed, there is by now a long tradition of studies that have discussed children and media such as television (see Luke, 1990). Critics like Postman (1986) argue that excessive TV-viewing stunts cognitive growth, creates shortened attention spans, and habituates youth to fragmented, segmented, and imagistic cultural experiences and that thus television and other electronic media 
are a social problem for children. Defenders stress the educational benefits of some television, suggest that it is merely harmless entertainment, or argue that audiences construct their own meanings from popular media (Fiske, 1989 and 1993).

Negative depictions of the media and consumerism, youth hedonism, excessive materialism, and growing violence were contested by British cultural studies that claimed that the media were being scapegoated for a wide range of social problems. In Policing the Crisis (Hall et al, 1978), Stuart Hall and colleagues at the Birmingham Centre for Contemporary Cultural Studies analyzed what they took to be a media-induced "moral panic" about mugging and youth violence. The Birmingham group argued for an active audience that was able to critically dissect and make use of media material, arguing against the media manipulation perspective. Rooted in a classic article by Stuart Hall titled "Encoding/Decoding" (1980), British cultural studies began studying how different groups read television news, magazines, engaged in consumption, and made use of a broad range of media. In Everyday Television: Nationwide Charlotte Brunsdon and David Morley (1978) studied how difference audiences consumed TV news; Ien Ang (1985) and Liebes and Katz (1990) investigated how varying audiences in Holland, Israel, and elsewhere consumed and made use of the U.S. TV-series Dallas; and John Fiske (1987; 1989a and 1989b) wrote a series of books celebrating the active audience and consumer in a wide range of domains by audiences throughout the world.

Yet critics working within British cultural studies, individuals in a wide range of social movements, and academics from a variety of fields and positions began criticizing the media from the 1960s and to the present for promoting sexism, racism, homophobia, and other oppressive social phenomena. There was intense focus on the politics of representation, discriminating between negative and positive representations of major social groups and harmful and beneficial media effects, debates that coalesced under the rubric of the politics of representation.

\section{Oppositional Social Movements and the Politics of Representation}

Much television criticism of the $1960 \mathrm{~s}$ was somewhat unsophisticated and underdeveloped theoretically, often operating with reductive notions of political economy; simplistic models of media effects; and one-dimensional models of media messages. Yet from the 1960s to the present, a wide-range of critical theories circulated globally and many working within television studies appropriated the advanced critical discourses.

The groundbreaking work of critical media theorists within the Frankfurt School, British Cultural Studies, and French structuralism and poststructuralism revealed that culture is a social construct, intrinsically linked to the vicissitudes of the social and historically specific milieu in which it is conceived and that gender, race, class, sexuality, and other dimensions of social life are socially constructed in media representations (see Durham and Kellner, 2001). Media and cultural studies engaged in critical interrogations of the politics of representation, which drew upon feminist and gay and lesbian approaches, as well as critical race and multicultural theories, to fully analyze the functions of gender, class, race, ethnicity, nationality, sexual preference and other key issues in television and the media.

The social dimensions of media constructions of axis of difference and subordination are perceived by cultural studies as being vitally constitutive of audiences who appropriate and use 
texts. These approaches were strongly influenced by the social movements of the era. The feminist movement opposed media representation of women and criticized ones claimed to be sexist and inadequate, while calling for more positive representations of women and the participation of more women in the culture industries. Black and brown power movements criticized representations of people of color and militated for more inclusion in television and other media, as well as more realist and positive depictions. Likewise, gay and lesbian movements criticized the media for their neglect or misrepresentations of alternative sexuality and more representation.

All of these oppositional movements developed critical perspectives on television and often produced new forms of TV criticism, positioning the politics of representation as a crucial part of television studies. ${ }^{6}$ Developments within British cultural studies are representative of this move toward a more inclusive politics of representation and TV criticism. While earlier British cultural studies engaged the progressive and oppositional potential of working class and then youth culture, under the pressure of the social movements of the 1960s and 1970s, many adopted a feminist dimension, paid greater attention to race, ethnicity and nationality, and concentrated on sexuality. During this period, assorted discourses of race, gender, sex, nationality and so on developed within a now global cultural studies. An increasingly complex, culturally hybrid and diasporic global culture and networked society calls for sophisticated understandings of the interplay of representations, politics, and the forms of media,

Although a vigorous feminist film and cultural criticism emerged by the 1970s, little feminist TV criticism emerged until the 1980s. ${ }^{7}$ As with feminist film criticism, early efforts focused on image and representations of women, but soon there was more sophisticated narrative analysis that analyzed how television and the narrative apparatus positioned women, the ways that television constructed femininity and masculinity, as well as more sociological and institutional analysis of how TV functioned in women's everyday life and how the institutions of television was highly male-dominated and patriarchal and capitalist in structure.

Tania Modleski (1983), for instance, followed a ground-breaking essay by Carol Lopate (1976) on how the organization of TV day followed the patterns of women's lives. Soap operas present a fragmented ongoing narrative that provides distraction and fantasies for women at home while ideologically positioning women in traditional stereotyped roles. The moral ambiguities and openness of the form provide spaces for multiple viewers, make possible varied readings, and provide predictable pleasures for its audiences. Addressing the alteration between the soap narratives and those of commercials, Modleski suggests that these modes address women's dual roles as "moral and spiritual guides" and "household drudges," thus reproducing the values and subject positions of patriarchal capitalism.

Many gay and lesbian theorists decried the ways that media representations promoted homophobia by presenting negative representations of gay sexuality. Larry Gross' "Out of the mainstream: Sexual minorities and the mass media" (1989) argues that corporate media culture defines and frames sexuality in ways that marginalize gay and lesbians, and "symbolically annihilate" their lives. Stereotypic depiction of lesbians and gay men as "abnormal, and the suppression of positive or even 'unexceptional' portrayals, serve to maintain and police the boundaries of the moral order" (1989: 136) in Gross' view. He argues for alternative representations -- a call that has to a certain degree been heard and answered by gay and lesbian 
media producers coming to prominence in the contemporary era, with even U.S. network television eventually presenting gay and lesbian characters.

A variety of critics of color have engaged racist representations in film, television, and other domains of media culture. ${ }^{8}$ Herman Gray (1995), for example, scrutinizes the related trajectory of black representation on network television in an analysis that takes into account the structures and conventions of the medium as well as the sociopolitical conditions of textual production. Gray's examination of race and representation highlights the articulations between recent representations of blacks and much earlier depictions. He argues that "our contemporary moment continues to be shaped discursively by representations of race and ethnicity that began in the formative years of television" (1995: 73). Contemporary cultural production is still in dialogue with these earliest moments, he writes, and he is aware of the regressive as well as the progressive aspects of this engagement. Importantly, Gray identifies certain turning points in television's representation of blackness, situating these "signal moments" within the cultural and political contexts in which they were generated. His analysis brings us to a confrontation with the possibilities of mass cultural texts engaging the politics of difference in a complex and meaningful way.

Many critics emphasized the importance of connecting representations of gender, race, class, sexuality, and other subject positions to disclose how the media present socially derogatory representations of subordinate groups. bell hooks (1992) has been among the first and most prolific African-American feminist scholars to call attention to the interlockings of race, class, gender and additional markers of identity in the constitution of subjectivity. Early in her career she challenged feminists to recognize and confront the ways in which race and class inscribe women's (and men's) experiences. In "Eating the Other" (1992), hooks explores cultural constructions of the "Other" as an object of desire, tying such positioning to consumerism and commodification as well as to issues of racial domination and subordination. Cautioning against the seductiveness of celebrating "Otherness," hooks uses various media cultural artifacts -clothing catalogs, films, television, and rap music -- to debate issues of cultural appropriation versus cultural appreciation, and to uncover the personal and political crosscurrents at work in mass media representation.

Elaine Rapping has written a series of books engaging dynamics of gender, race, and class while relating television to current social and political issues. The Looking Glass World of Nonfiction Television (1986) provides a study of local and national news, game shows, national rituals, beauty pageants, and presidential politics, as well as studies of TV documentaries, special reports, and soft news. Her studies of made-for-TV movies was expanded into The Movie of the Week (1992) a ground-breaking analysis of TV-movies which had hitherto been somewhat ignored my both film and television scholars. Her recent Law and Justice As Seen on TV (2003) traces the history of crime drama and courtroom drama and the ways that actual crimes and problems of justice are represented in TV frames and dramas from the Menendez brothers trial, to the O.J. Simpson murder trials, and Timothy McVeigh's Oklahoma City bombing case.

TV representations often construct women, people of color, and members of various minorities and their social problems as victims and objects, and mainstream television rarely presents positive representations of women's movements or collective forms of struggle, rather focusing on women as individual examples of specific social problems like rape or domestic 
violence. Likewise, television series featuring people of color often appropriate groups like African Americans or Latinos into typical white middle class American behavior, values, and institutions, rather than articulating cultural specificity or showing oppressed groups voicing criticisms or organizing into political movements.

Just as critical television critics came to insist on the interaction of the politics of representation in race, gender, class, sexuality, and other key dimensions, so too did critical television scholars began to integrate studies of the TV industry, texts, audiences, and social context into their work. For instance, in a ground-breaking work on Cagney and Lacey, Julie D'Acci calls for an "integrated approach" that analyzes how the politics of representation play out in the television production process, on the level of the construction and unfolding of TV texts and narratives, on the level of audience reception, and within the context of specific sociohistorical environments $(1994,2002)$. Such "modern approaches," however, were criticized by a postmodern turn in television and cultural studies.

\section{The Postmodern Turn within Critical Television Studies}

During the 1980s and 1990s, many noticed a postmodern turn toward cultural populism that valorized audiences over texts and the production apparatus, the pleasures of television and popular culture over their ideological functions and effects, and that refocused television criticism on the surface of its images and spectacle, rather than deeper embedded meanings and complex effects (see Best and Kellner, 1987, McGuigan 1992 and Kellner 1995). If for most of the history of television, narrative storytelling has been the name of the game, on a postmodern account of television, image and spectacle often decenters the importance of narrative. It is often claimed that in those programs usually designated "postmodern" -- MTV music videos and other programming, Miami Vice, Max Headroom, Twin Peaks, high-tech ads, and so on -- there is a new look and feel: the signifier has been liberated and image takes precedence over narrative, as compelling and highly artificial aesthetic spectacles detach themselves from the television diegesis and become the center of fascination, of a seductive pleasure, of an intense but fragmentary and transitory aesthetic experience.

While there is some truth in this conventional postmodern position, such descriptions are in some ways misleading. In particular, the familiar account that postmodern image culture is fundamentally flat and one-dimensional is problematic. For Fredric Jameson, postmodernism manifests "the emergence of a new kind of flatness or depthlessness, a new kind of superficiality in the most literal sense -- perhaps the supreme formal feature of all the postmodernisms" (1984: 60). According to Jameson, the "waning of affect" in postmodern image culture is replicated in postmodern selves who are allegedly devoid of the expressive energies and individualities characteristic of modernism and the modern self. Both postmodern texts and selves are said to be without depth and to be flat, superficial, and lost in the intensities and vacuities of the moment, without substance and meaning, or connection to the past.

Privileging Jameson's category of the waning of affect, Gitlin (1987), for example, claims that Miami Vice is the ultimate in postmodern blankness, emptiness, and world-weariness. Yet, against this reading, one could argue that it pulsates as well with intense emotion, a clash of values, and highly specific political messages and positions (see Best/Kellner 1987 and Kellner 
1995). Grossberg (1987) also argues that Miami Vice and other postmodern culture obliterates meaning and depth, claiming: "Miami Vice is, as its critics have said, all on the surface. And the surface is nothing but a collection of quotations from our own collective historical debris, a mobile game of Trivia. It is, in some ways, the perfect televisual image, minimalist (the sparse scenes, the constant long shots, etc) yet concrete" (1987: 28). Grossberg goes on to argue that "indifference" (to meanings, ideology, politics, and so on) is the key distinguishing feature of Miami Vice and other postmodern texts which he suggests are more akin to billboards to be scanned for what they tell us about our cultural terrain rather texts to be read and interrogated.

Against these postmodern readings, I would argue that Miami Vice is highly polysemic and is saturated with ideologies, messages, and quite specific meanings and values. Behind the high tech glitz are multiple sites of meaning, multiple subject positions, and highly contradictory ideological problematics. The show had a passionately loyal audience that was obviously not indifferent to the series that had its own intense affective investments and passions. I have argued that reading the text of Miami Vice hermeneutically and critically provides access to its polysemic wealth and that therefore it is a mistake to rapidly speed by such artifacts, however some audiences may relate to them (Kellner 1995: 238ff).

One-dimensional postmodern texts and selves put in question the continued relevance of hermeneutic depth models such as the Marxian model of essence and appearance, true and false consciousness, and ideology and truth; the Freudian model of latent and manifest meanings; the existentialist model of authentic and inauthentic existence; and the semiotic model of signifier and signified. Cumulatively, postmodernism thus signifies the death of hermeneutics; in place of what Ricoeur (1970) has termed a "hermeneutics of suspicion" and the polysemic modernist reading of cultural symbols and texts, there emerges the postmodern view that there is nothing behind the surface of texts, no depth or multiplicity of meanings for critical inquiry to discover and explicate.

From this view of texts and selves, it follows that a postmodern television studies should rest content to describe the surface or forms of cultural texts, rather than seeking meanings or significance. Best and Kellner (1987) have polemicized against the formalist, anti-hermeneutical postmodern type of analysis connected with the postulation of a flat, postmodern image culture and we have delineated an alternative model of a "political hermeneutic" which draws on both postmodern and other critical theories in order to analyze both image and meaning, surface and depth, as well as the politics and erotics of cultural artifacts. Such an interpretive and dialectical analysis of image, narrative, ideologies, and meanings is arguably still of importance in analyzing even those texts taken to be paradigmatic of postmodern culture -- though analysis of form, surface, and look is also important. Images, fragments, and narratives of media culture are saturated with ideology and polysemic meanings, and that therefore -- against certain postmodern positions (Foucault 1977; Baudrillard 1981; and Deleuze/Guattari 1977) -- ideology critique continues to be an important and indispensable weapon in our critical arsenal. ${ }^{9}$

Another problematic postmodern position, associated with Baudrillard (1983b and 1983c), asserts that television is pure noise and a black hole where all meaning and messages are absorbed in the whirlpool and kaleidoscope of the incessant dissemination of images and information to the point of total saturation, where meaning is dissolved and only the fascination of discrete images glow and flicker in a mediascape within which no image any longer has any 
discernible effects. On the Baudrillardian view, the proliferating velocity and quantity of images produces a postmodern mindscreen where images fly by with such rapidity that they lose any signifying function, referring only to other images ad infinitum, and where eventually the multiplication of images produces such saturation, apathy, and indifference that the telespectator is lost forever in a fragmentary fun house of mirrors in the infinite play of superfluous, meaningless images.

Now, no doubt, television can be experienced as a flat, one-dimensional wasteland of superficial images, and can function as well as pure noise without referent and meaning. One can also become overwhelmed by -- or indifferent to -- the flow, velocity, and intensity of images, so that television's signifying function can be decentered and can collapse altogether. Yet people regularly watch certain shows and events; there are fans for various series and stars who possess an often incredible expertise and knowledge of the subjects of their fascination; people do model their behavior, style, and attitudes on television images and narratives; television ads do play a role in managing consumer demand; and many analysts have concluded that television is playing the central role in political elections, that elections have become a battle of images played out on the television screen, and that television is playing an essential role in the new art of governing (Kellner 1990, 1992, 1995, 2001, and 2003a and 2003b).

As British cultural studies have long argued, different audiences watch television in different ways. For some, television is nothing more than a fragmented collage of images that people only fitfully watch or connect with what goes before or comes after. Many individuals today use devices to "zap" from one program to another, channel hopping or "grazing" to merely "see what's happening," to go with the disconnected flow of fragments of images. Some viewers who watch entire programs merely focus on the surface of images, with programs, ads, station breaks, and so on flowing into each other, collapsing meaning in a play of disconnected signifiers. Many people cannot remember what they watched the night before, or cannot provide coherent accounts of the previous night's programming.

And yet it is an exaggeration to claim that the apparatus of television itself relentlessly undermines meaning and collapses signifiers without signifieds into a flat, one-dimensional hyperspace without depth, effects, or meanings. Thus, against the postmodern notion of culture disintegrating into pure image without referent or content or effects -- becoming at its limit pure noise - many critics argue that television and other forms of mass-mediated culture continue to play key roles in the structuring of contemporary identity and shaping thought and behavior. Television today arguably assumes some of the functions traditionally ascribed to myth and ritual (i.e. integrating individuals into the social order, celebrating dominant values, offering models of thought, behavior, and gender for imitation, and so on; see Kellner 1979 and 1995). In addition, TV myth resolves social contradictions in the way that Levi-Strauss described the function of traditional myth and provided mythologies of the sort described by Barthes that idealize contemporary values and institutions, and thus exalt the established way of life (Kellner 1979 and 1982).

Consequently, much postmodern cultural analysis is too one-sided and limited, in either restricting its focus on form, on image and spectacle alone, or in abandoning critical analysis altogether in favor of grandiose totalizing metaphors (black holes, implosion, excremental culture, and so on). Instead, it preferable to analyze both form and content, image and narrative, and 
postmodern surface and the deeper ideological problematics within the context of specific exercises which explicate the polysemic nature of images and texts, and which endorse the possibility of multiple encodings and decodings.

Thus, I would conclude that critical perspectives developed by the Frankfurt School, British cultural studies, and other scholars who focus on dissection of television production and political economy, texts, audience reception, and socio-political context in a multiperspectivist framework provide the most comprehensive and flexible model for doing critical television studies. For some projects, one may choose to intensely pursue one perspective (say, feminism or political economy), but for many projects articulating together salient critical perspectives provides a more robust approach that helps to grasp and critique television's multifaceted production, texts, effects, and uses.

To avoid the one-sidedness of textual analysis approaches, or audience and reception studies, I propose that critical television studies itself be multiperspectival, getting at culture from the perspectives of political economy, text analysis, and audience reception, as outlined above. Textual analysis should utilize a multiplicity of perspectives and critical methods, and audience reception studies should delineate the wide range of subject positions, or perspectives, through which audiences appropriate culture. This requires a multicultural approach that sees the importance of analyzing the dimensions of class, race and ethnicity, and gender and sexual preference within the texts of television culture, while studying as well their impact on how audiences read and interpret TV.

In addition, a critical television studies attacks sexism, racism, or bias against specific social groups (i.e. gays, intellectuals, and so on), and criticizes texts that promote any kind of domination or oppression. As an example of how considerations of production, textual analysis, and audience readings can fruitfully intersect in cultural studies, let us reflect on the Madonna phenomenon. Madonna first appeared in the moment of Reaganism and embodied the materialistic and consumer-oriented ethos of the 1980s ("Material Girl"). She also appeared in a time of dramatic image proliferation, associated with MTV, fashion fever, and intense marketing of products. Madonna was one of the first MTV music video superstars who consciously crafted images to attract a mass audience. Her early music videos were aimed at teen-age girls (the Madonna wanna-be's), but she soon incorporated black, Hispanic, and minority audiences with her images of interracial sex and multicultural "family" in her concerts. Madonna also appealed to gay and lesbian audiences, as well as to feminist and academic audiences, as her videos became more complex and political (i.e. "Like a Prayer," "Express Yourself," "Vogue," and so on).

Thus, Madonna's popularity was in large part a function of her marketing strategies and her production of music videos and images that appealed to diverse audiences. To conceptualize the meanings and effects in her music, films, concerts, and public relations stunts requires that her artifacts be interpreted within the context of their production and reception, which involves discussion of MTV, the music industry, concerts, marketing, and the production of images (see Kellner 1995). Understanding Madonna's popularity also requires focus on audiences, not just as individuals, but as members of specific groups, such as teen-age girls, who were empowered in their struggles for individual identity by Madonna, or gays, who were also empowered by her incorporation of alternative images of sexuality within popular mainstream cultural artifacts. Yet appraising the politics and effects of Madonna also requires analysis of how her work might 
merely reproduce a consumer culture that defines identity in terms of images and consumption. It would make an interesting project to examine how former Madonna fans view the evolution and recent incarnations of the superstar, such as her second marriage to British director Guy Richey and 2001 Drowned World tour, as well as to examine how contemporary fans view Madonna in an age that embraces younger teen pop singers like Britney Spears or Mariah Carey.

In short, a television studies that is critical and multicultural provides comprehensive approaches to culture that can be applied to a wide variety of artifacts from TV series to phenomena like Madonna, from MTV to TV news, or to specific events like the 2000 U.S. presidential election (Kellner 2001), or media representations of the 2001 terrorist attacks on the U.S. and the U.S. response (Kellner 2003a). Its comprehensive perspectives encompass political economy, textual analysis, and audience research and provide critical and political perspectives that enable individuals to dissect the meanings, messages, and effects of dominant cultural forms. A critical television and cultural studies is thus part of a media pedagogy that enables individuals to resist media manipulation and to increase their freedom and individuality. It can empower people to gain sovereignty over their culture and to be able to struggle for alternative cultures and political change. Cultural studies is thus not just another academic fad, but can be part of a struggle for a better society and a better life.

\section{$\underline{\text { References }}$}

Adorno, T.W. (1941) "On Popular Music," (with G. Simpson), Studies in Philosophy and Social Science, Vol. 9, no 1: 17-48.

(1978 [1932]) "On the Social Situation of Music," Telos 35 (Spring): 129-

165.

(1982) "On the Fetish Character of Music and the Regression of Hearing," in Arato and Gebhardt 1982: 270-299.

(1989) "On Jazz," in Bronner and Kellner 1989: 199-209.

(1991) The Culture Industry. London: Routledge.

(1994) The Stars Down to Earth and Other Essays on the Irrational in

Culture. London: Routledge.

Adorno, T. W. et al (1969 [1950]) The Authoritarian Personality. New York: Norton, 1969).

Ang, Ien (1985) Watching Dallas. New York: Metheun.

Arato, Andrew and Eike Gebhardt (1982) The Essential Frankfurt School Reader. New

York: Continuum.

Baudrillard, Jean (1981 [1973]) For a Critique of the Political

Economy of the Sign. St. Louis: Telos Press.

(1983a) Simulations. New York: Semiotext(e).

(1983b) In the Shadow of the Silent Majorities.

New York: Semiotext(e).

Bell, Daniel (1978) The Cultural Contradictions of Capitalism. New York: Basic Books.

Benjamin, Walter (1969) Illuminations. New York: Shocken. 
Best, Steven and Douglas Kellner(2001). The Postmodern Adventure. Science Technology, and Cultural Studies at the Third Millennium. New York and London: Guilford and Routledge. Bloch, Ernst (1986) The Principle of Hope. Cambridge: MIT Press.

Bronner, Stephen and Kellner, Douglas (1989) Critical Theory and Society. A Reader. New York: Routledge.

Brunsdon, Charlotte and David Morley (1978) Everyday Television: "Nationwide." London: British Film Institute.

Brunsdon, Charlotte, D’Acci, Jule and Spigel, Lynn (eds) (1997) Feminist television

Criticism: A Reader. Oxford: Oxford University Press.

Deleuze, Gilles, and Felix Guattari (1977) Anti-Oedipus. New

York: The Viking Press.

Dines, Gail and Jean M. Humez, (eds.) (2003) Gender, Race, and Class in Media. Sage.

London and Thousand Oaks, Ca.

Durham, Meenakshi Gigi and Douglas Kellner, editors (2001) Media and Cultural Studies:

KeyWorks. Malden, Mass. and Oxford, UK: Blackwell.

Fiske, John (1986) "British Cultural Studies and Television." In R. C. Allen (Ed.),

Channels of Discourse. Chapel Hill: University of North Carolina Press, 254-289.

Fiske, John (1987) Television Culture. New York and London: Routledge.

Fiske, John (1989a) Reading the Popular. Boston: Unwin Hyman.

Fiske, John (1989b) Understanding Popular Culture. Boston: Unwin Hyman.

Foucault, Michel (1977) Language, Counter-Memory, Practice. New York: Cornell University.

Gerbner, George (2003) "Television Violence: At a Time of Turmoil and Terror," in Dines and Humez, 2003: 339-348.

Gitlin, Todd (1972) "Sixteen Notes on television and the Movement." In George White and Charles Newman, eds., literature and revolution. New York: Holt, Rinehart and Winston.

(1980) The Whole World is Watching. Berkeley: University of California Press.

(1983) Inside Prime Time. New York: Pantheon.

Gitlin, Todd, editor (1987) Watching Television. New York: Pantheon.

(2002) Media Unlimited. How the Torrent of Images and Sounds

Overwhelms Our Lives. New York: Metropolitan Books.

Gray, Herman. 1995. "The politics of representation in network television." In Watching

Race: Television and the Struggle for "Blackness", 70-92. Minneapolis: University of Minnesota Press.

Gross, Larry. 1989. "Out of the mainstream: Sexual minorities and the mass media." In Remote Control: Television, Audiences and Cultural Power, ed. Ellen Seiter, 130-149. New York: Routledge.

Gross, Larry, and Woods, James D. 1999. "Introduction: Being gay in American media and society." In The Columbia Reader on Lesbians and Gay Men in Media, Society, and Politics, 322. New York: Columbia University Press.

Grossberg, Lawrence (1987) "The In-Difference of Television," 
Screen, Vol. 28, Nr. 2: 28-46.

Hall, Stuart et al (1978) Policing the Crisis: Mugging, the State, and Law and Order.

London: Macmillan.

Hall, Stuart (1980) "Encoding and Decoding" in Culture, Media, Language. London:

Hutchinson.

Herman, Edward, and Noam Chomsky (1988). Manufacturing Consent: The Political Economy of the Mass Media. New York: Pantheon.

Herzog, Herta (1941), "On Borrowed Experience. An Analysis of Listening to Daytime

Sketches," Studies in Philosophy and Social Science, Vol. IX, No. 1: 65-95.

hooks, bell. 1992. "Eating the other: Desire and resistance." In Black Looks: Race and Representation, 21-39. Boston: South End Press

Horkheimer, Max and T.W. Adorno (1972) Dialectic of Enlightenment. New York:

Herder and Herder.

Jay, Martin The Dialectical Imagination, (Boston, Little, Brown and Company, 1973).

Jhally, Sut and Lewis, Justin (1992) Enlgithened Racism: The Cosby Show, Audiences, and the Myth of the American Dream. San Francisco: Westview Press.

Kellner, Douglas (1989) Critical Theory, Marxism, and Modernity. Cambridge and Baltimore: Polity and John Hopkins University Press.

Press.

(1990) Television and the Crisis of Democracy. Boulder, Col.: Westview

(1990). Television and the Crisis of Democracy. Boulder: Westview Press.

(1992) The Persian Gulf TV War. Boulder: Westview Press.

(1995) Media Culture. Cultural Studies, Identity, and Politics Between

the Modern and the Postmodern. London and New York: Routledge.

(1997) "Critical Theory and British Cultural Studies: The Missed

Articulation," in Cultural Methodologies, edited by Jim McGuigan. London: Sage: 12-41.

(2001) Grand Theft 2000. Lanham, Md.: Rowman and Littlefield.

(2003a) Media Spectacle. New York and London: Routledge.

(2003b) September 11 and Terror War: The Dangers of the Bush Legacy. Lanham,

Md.: Rowman and Littlefield.

Kracauer, Siegfried (1995) The Mass Ornament. Cambridge, Mass.: Harvard University

Press.

Lazarsfeld, Paul (1941) "Administrative and Critical Comunications Research," Studies in

Philosophy and Social Science, Vol. IX, No. 1: 2-16.

Lewis, Justin "Mass Communication Studies," in Miller 2002: 4-6.

Lowenthal, Leo (1957) Literature and the Image of Man. Boston: Beacon Press.

Prentice-Hall.

(1961) Literature, Popular Culture and Society. Englewood Cliffs, New Jersey:

Luke, Carmen (1990) TV and Your Child. London: Angus and Robertson.

Marcuse, Herbert (1955) Eros and Civilization. Boston: Beacon Press.

Marcuse, Herbert (1964) One-Dimensional Man. Boston: Beacon Press.

McGuigan, Jim (1992) Cultural Populism. London and New York: Routledge.

Miller, Toby (2002) (ed.) Television Studies. London: BFI Publishing. 
Modleski, Tania (1982) Loving with a Vengeance: Mass-Produced Fantasies for Women.

Hamden: Anchor.

Morley, David (1986) Family Television. London: Comedia.

Noriega, Chon (2000) Shot in America: Television, the State, and the Rise of Chicano

Cinema. Durham: Duke University Press.

Russo, and L. Torres (Eds.), Third World Women and the Politics of Feminism, 51-80.

Bloomington: Indiana University Press.

Postman, Neil (1986) Amusing Ourselves to Death. Public Discourse in the Age of Show Business.

New York: Viking.

Rapping, Elaine (1986) The Looking Glass World of Nonfiction Television. Boston: South End

Press.

(1992) The Movie of the Week. Minneapolis: University of Minnesota Press.

(2003) Law and Justice As Seen on TV. New York: New York University Press.

Rosenberg, Bernard and David Manning White, editors (1957) Mass Culture. Glencoe, Ill:

The Free Press.

Schiller, Herbert (1971) Mass communications and the American Empire. Boston: Beacon Press.

Sreberny, Annabelle (2002), "Media Imperialism," in Miller 2002: 21-23.

Steinert, Heinz (2003) Culture Industry. Cambridge, UK: Polity Press.

Sussman, Gerald "The Political Economy of television," in Miller 2002: 7-10.

Torres, Sasha (ed.) (1998) Living Color: Race and television in the United States. Durham: Duke

University Press.

Tunstall, Jeremy (1977) The media are American. New York: Columbia University Press.

White, Mimi (1986) "Ideological Analysis of Television," in Allen 1986: 134-171.

Wiggershaus, Rolf (1994), The Frankfurt School. Cambridge, UK: Polity Press.

\section{$\underline{\text { Notes }}$}

${ }^{1}$ On the history of the Frankfurt School, see Jay 1973 and Wiggershaus 1994; for Frankfurt School readers, see Arato and Gebhardt 1982 and Bronner and Kellner 1989; for appraisal of Frankfurt School social and media critique, see Kellner 1989a and Steinert 2003.

${ }^{2}$ For critical analysis and appreciation of the Frankfurt School approach to media and television studies, see Kellner 1989, 1995, and 1997, and Steinert 2003.

${ }^{3}$ For useful overviews of political economy research in television studies, see Sussman in Miller 2002; for an excellent overview of discourses of media imperialism, including analysis of how the concept has become problematic in a more pluralized and hybridized global media world, see Sreberny in Miller 2002.

${ }^{4}$ For a survey of studies of television and violence, see Morgan in Miller 2002.

${ }^{5}$ See the studies depicting both sides of the debate on contemporary television and its alleged harmful or beneficial effects in Barbour, 1994 and in Dines and Humez, 2003.

${ }^{6}$ For examples of studies of the politics of representation, see Gilroy 1991; McRobbie 1994; Ang 1998, and texts collected in Durham and Kellner, 2001 and Dines and Humez 2003. 
${ }^{7}$ For an excellent account of the genesis of feminist TV criticism by one of its major participants, see Kaplan 1987. For an anthology of feminist TV criticism, see Brunsdon, D'Accci and Spigel 1997, and for overviews of feminist TV criticism in the contemporary moment see the studies collected under Gender in Miller 2002.

${ }^{8}$ On race and representation in television, see the Jhally and Lewis 1992, Hamamoto 1994, Gray 1995, the 1998 anthology edited by Torres, and Noriega 2000.

${ }^{9}$ See Kellner 1995 for discussion of the issues at stake here and a program for combining ideology critique with formalist analysis, sociological interpretation and political critique. On ideology critique in television studies, see White 1986. 